\title{
Attitudes of Customers towards Applying the Marketing Mix in Non-Governmental Organizations (NGOs)
}

\author{
Dr. Tareq N. Hashem \\ Associate Professor, Marketing Department \\ Isra University, Amman, Jordan \\ Abeer A. Alqirem \\ Master of Public Administration \\ University of Jordan, Amman, Jordan
}

\begin{abstract}
In recent years, marketing has witnessed a remarkable development. We can see that the greatest emphasis was laid upon profit and that is applied in $N G O(s)$. As for the field of marketing, it emphasized the service that is provided to the beneficiaries. Marketing was misunderstood by beneficiaries due to linking marketing with price and that shed a light upon the trends that concern the used marketing mix. Unfortunately, due to the emergence of globalization and the increasing the number of beneficiaries who benefit from services, some organizations found that the traditional funding sources are not sufficient to meet their needs and serve the community. Thus, we had to resort to modern marketing methods which are called "the marketing mix". Thus, this study was performed to investigate the attitudes of beneficiaries towards applying the marketing mix in non-governmental organizations (NGOs). To achieve the goals of this study and to provide answers for its questions, the researchers developed a questionnaire. This questionnaire was distributed to a sample that consisted of 500 employees who received loans from NGOs and lived in Amman. The response rate was $77 \%$. The study concluded that there are positive attitudes towards applying the marketing mix in NGOs. Furthermore, it was also conclude that there is a relationship that is statistically significant between the sample's attitudes towards applying the marketing mix in NGOs and the samples' income.
\end{abstract}

Keywords: Non-Governmental Organizations (NGOs), Marketing Mix, Product, Price, Place, Promotion.

\section{INTRODUCTION}

The role of marketing in non-governmental organizations has grown over the last forty years. For instance, these organizations have realized the value of marketing in strengthening the familiarity of the customers and other stakeholders with the product or service. (Baines and Fill, 2014). Studies have showed that the number of NGOs has increased tenfold over the past ten years (Cramer, 2001). NGOs mission lies in managing resources and implementing projects which aim at addressing the social projects. NGOs are of great importance and value in the modern society. Thus, there is a need to have marketing strategies that can help these organizations in accessing more beneficiaries (Yazdanifard et al., 2013). NGOs usually refer to the groups that work in the field of promoting environmental or social objectives rather than achieving economic power in the market or political power (Yazdanifard et al., 2013). The presence of NGOs is for the benefit of society, though there is a variety of a reasons behind the existence of these organizations.

\section{MeThodology}

\subsection{The Study Problem \& its Questions}

NGO marketing is a concept that few customers support it. Thus, it is necessary to shed a light upon customers' attitudes towards applying the marketing mix in NGOs. That is done through providing an answer for the following questions:

a) What are the customers' attitudes towards applying the marketing mix in NGOs?

b) Are there any differences that are statistically significant in the sample's attitudes towards applying the marketing mix in NGOs, which can be attributed to their past experience of dealing with NGOs? 
c) Is there any relationship that is statistically significant between the sample's attitudes towards applying the marketing mix in NGOs and the samples' income?

\subsection{The Study Importance}

The importance of NGOs lies in providing a service that will not be provided by the business sector. For instance, these organizations can help the citizens in making contributions to their communities (Wymer, 2006). Some studies have suggested that the fate of NGOs depends on the degree of accessing resources (Galaskiewicz and Bielefeld, 1998). Their fate also depends on the type of resources which NGOs depend on to identify the market orientation (Macedo \& Pinho, 2003). Most marketing strategies in NGOs are concerned with the methods of preserving the existence of the organization and maintaining its stability (Yazdanifard et al., 2013). In order to respond to the faced challenges effectively, it was necessary to adopt a marketing orientation to manage the organization (Wymer, 2006). Some studies have confirmed that most NGOs rely on traditional marketing methods and means (Wymer, 2006). For instance, they depend on donations (Brace-Govan et al., 2011). Thus, NGOs must learn to invent newer and better ways to market themselves. NGOs use marketing methods to build up and construct their image and reputation within the community (Wymer, 2006). Most of the researchers believe that the adopting a marketing strategy is considered important for the benefit of NGOs (Sara\& Katie, 2009), (Macedo and Pinho, 2006). The market share reflects the extent of success of the marketing strategy (Nuseir and Madanat, 2015) (Bee, 2009) (Li and Green, 2010). Organizations develop marketing strategies, because they seek to achieve the numerous wishes of the beneficiaries. The aim of marketing strategies lies in providing beneficiaries with benefits, in exchange for building up a strong relationship with them through meeting their needs (Nuseir and Madanat, 2015) (Singh, 2012) (Middleton,2001) (Keegan and Green, 2011).

\subsection{The Study Objectives}

This study seeks to obtain a number of the objectives are the following:

a. Characterize the importance of applying marketing mix in NGOs.

b. Measure the customers' attitudes towards applying the marketing mix in NGOs.

c. Provide some recommendations may be useful to community, NGOs and government agencies.

\subsection{The Study Hypotheses}

H01 - Customers have negative attitudes towards applying the marketing mix in NGOs.

H02 - There are no differences that are statistically significant in the sample's attitudes towards applying the marketing mix in NGOs, which can be attributed to their past experience of dealing with NGOs.

H03 - There is no relationship that is statistically significant between the sample's attitudes towards applying the marketing mix in NGOs and their income.

\section{TheOretical FrameWORK \& LiTERATURE REVIEW}

\subsection{Theoretical Framework}

\subsubsection{Non-governmental Organization (NGOs)}

Non-governmental organizations (NGOs) are non-profit organizations. They are not related to the government, and they work for social purposes. They gain their funding from private sources (Yazdanifard et al., 2013) (Cramer, 2001). NGOs differ from each other in their lands extension and management structures. Some of them are multinational organizations. Such type of organizations refer to the organization which have a headquarters in one country and many other branches in a number of other countries. Other NGOs are considered local organization with a local or countrywide focus (Cramer, 2001). The sources that fund NGOs include the donors, government, companies and individuals. NGOs are not affiliated with the government and are not considered as being private companies that depend on the profit system. NGOs are usually full of volunteers, and such kind of organization are considered non-profit organizations (Yazdanifard et al., 2013) (Wymer, 2006). NGOs exist in environments that are constantly changing. In order for these organizations to be effective, they have to predict the surrounding changes and must be aware of the technological, political, social and economic impacts which may influence them. NGOs must cope with the surrounding community 
(Wymer, 2006). Furthermore, NGOs have to come up with newer ways to manage resources more efficiently, in order to achieve the desired goals. The goals of these organizations are more oriented towards the beneficiaries in the market, rather than being oriented towards the donors. (Macedo \& Pinho, 2003) (Brace-Govan et al., 2011).

\subsubsection{Marketing Mix in $\mathrm{NGO}(\mathrm{s})$}

Marketing mix is a set of four elements. These elements include: product, price, place and promotion. The successful marketing mix is important for helping marketers in selecting the destination that can achieve their goals and create a demand on their products or services. Marketers can help the organization in making strategic decisions that are necessary to create a competitive advantage (Sara\& Katie, 2009) (Singh, 2012). For instance, marketers can help in suggesting offers on products, that are directed to the target market (Kamau et al., 2015) (Pomering et al., 2010) (Yazdanifard et al., 2013) (Lamb et al., 2011). It should be noted that when choosing the desired place, price and promotion strategies, we must have at the beginning an idea about the product or service that will be sold in the market (Kamau et al., 2015). The primary reasons behind the use of the marketing mix is represented in seeking to achieve excellence in performance. That is done through identifying the needs and requirements of the beneficiaries and then seeking to fulfill them (Nuseir and Madanat, 2015) (Armstrong and Kotler, 2011) (Lamb et al., 2011) (Keegan and Green, 2011). Marketing strategy is a combination of two processes; data analysis and decision making. The best marketing strategy is when decision makers use the profit and budget to calculate a formula for the organization globally or locally. Thus, the organization can become larger and larger and the staff may become more enthusiastic about what they do (Yazdanifard et al., 2013) (Li and Green, 2010).

\subsubsection{Product}

The product can refer to a physical product or a service that the beneficiary is ready to pay for (Singh, 2012) (Cirikovic, 2014). In other words, products can refer to the goods and services that are put in the market to be consumed by the beneficiaries to meet their needs and requirements (Nuseir and Madanat, 2015) (Armstrong and Kotler, 2011) (Al Muala and Al Qurneh, 2012). Products may be physical, such as: hardware. They may also be in form of ideas, such as: the ideas that are suggested by consultants or in the form of services, such as: the services that are provided by the health care and education sectors (Lamb, et al., 2011). The product element is considered as a fundamental aspect of the marketing mix. Products can be distinguished from each other on the basis of their properties and characteristics (Nuseir and Madanat, 2015) (Lamb et al., 2011). Some studies have suggested that selecting the product shall not affect the marketing mix, but shall affect the organization's long-term growth strategies, policies, investments and human resources (Kamau, et al., 2015) (Middleton, 2001).

\subsubsection{Price}

The most significant element of the marketing mix can be seen differently from one NGO to another. However, Price is the value that is being placed upon the product or service that is being provided to the beneficiary (Lamb et al., 2011) (Nuseir and Madanat, 2015) (Al Muala and Al Qurneh, 2012). Price has an influence upon the beneficiary's behavior. It can affect the beneficiary's decision whether to repurchase the product or not. Product pricing decision depends on many factors, including the beneficiaries' purchasing power, product cost and the cost of delivering the product (Nuseir and Madanat, 2015) (Singh, 2012) (Markgraf, 2015) (Cirikovic, 2014). Price is the main factor behind achieving the beneficiary's satisfaction with the product, because the beneficiary is looking for getting the greatest possible amount of benefit for a lower price (Peter and Donnely, 2016). The studies of (Kamau et al., 2015) (Markgraf, 2015) have confirmed that price should be compatible with the product. The most important factor when making the product pricing decision is represented in estimating the cost of the product and marketing strategy, and the expenses that are related to the distribution and advertising expenses (Singh, 2012).

\subsubsection{Place}

It refers to the distribution channels, storage facilities, transportation routes and inventory control (Singh, 2012) (Lamb et al., 2011). It can be the actual site or can be selected in terms of the availability of the product to the beneficiaries and accessibility to it (Kamau, et al., 2015). Nuseir and Madanat (2015) and Armstrong and Kotler (2011) argued that selecting the place is linked to the availability of the product to the beneficiaries. The distribution facilities and location are key factors 
to meet the demand and supply of the product and to overcome the obstacles that may obstruct the process of supplying the product to the target market (Nuseir and Madanat, 2015).

\subsubsection{Promotion}

Promotion is considered one of the most significant element in the marketing mix. For instance, it can help the organization's sales department in displaying the product to the beneficiaries in an effective manner, and that can encourage them to buy it (Singh, 2012) (Markgraf, 2015) (Al Muala and Al Qurneh, 2012). Promotion is a way for announcing the product to the public in order to sell it to the beneficiaries. This process can be seen as a mean of communication with the beneficiaries, and that is done through using various means of advertising (Cirikovic, 2014). The essential aspect of promotion lies in minimizing the communication gap that occurs between the organization and the beneficiary. Strategic actions focus on exploiting the media advertising means to communicate with the beneficiaries and to attract and convince them in buying the product or the service (Nuseir and Madanat, 2015) (Lamb et al., 2011).

\section{Method And Procedures}

\subsection{The Study Approach}

The researchers adopted the descriptive analytical approach. The theoretical framework depended on books, periodicals, and electronic articles. As for the fieldwork, it was represented in designing a questionnaire that aimed to achieve the study's objectives, and was distributed the sample.

\subsection{The Study Population and its Sample}

The study's population included the beneficiaries who received loans from non- governmental organizations and who lived in Amman. As for the study's sample, it is a convenience sample, which consisted of 500 employees. 385 questionnaire forms were retrieved. Thus, the response rate was $77 \%$.

\subsection{Data Sources}

This study depended on two types of sources to collect the desired data that were processed statistically later. These sources are the following:

a. Primary source: These sources are represented in the study's questionnaire which was designed and distributed to the sample's subjects.

b. Secondary sources: This type of sources is represented in the books, references and previous studies which the study's researchers referred to, because they are related to the study's topic.

\subsection{The Reliability Test}

Cronbach Alpha test was conducted to identify the extent of the instrument's reliability. The calculated reliability value was $=0.735$. According to Malhotra( 2004), such value is considered approved, because it exceeds 0.60 .

\subsection{Statistical Processing Methods}

The program of statistical package for social sciences (SPSS) was used to process the data which have been collected through using the designed questionnaire. The following statistical methods were used to process the collected data: kindly advised to give why you use the following statistical techniques
a. Frequencies and percentages
b. Means and standard deviations
c. Independent sample $t$ test
d. Pearson correlation

\section{ANALYSIS AND DiscuSSION}

Frequency and percentages were calculated for the sample's demographic characteristics. 
Attitudes of Customers towards Applying the Marketing Mix in Non-Governmental Organizations (NGOs)

Table1. The Sample's Demographic Characteristics

\begin{tabular}{|l|l|l|}
\hline Category & Frequency & Percentage\% \\
\hline Education & 210 & 54.5 \\
\hline High School or less & 42 & 10.9 \\
\hline Diploma & 119 & 30.9 \\
\hline Bachelor & 14 & 3.6 \\
\hline Master & - & - \\
\hline PHD & 385 & 100.0 \\
\hline Total & 182 & \\
\hline Gender & 203 & 47.3 \\
\hline Male & 385 & 52.7 \\
\hline Female & \multicolumn{2}{l|}{} \\
\hline Total & 77 & 100.0 \\
\hline Marital Status & 280 & 20.0 \\
\hline Single & 21 & 72.7 \\
\hline Married & 7 & 5.5 \\
\hline Divorced & 385 & 1.8 \\
\hline Widow & \multicolumn{2}{l|}{} \\
\hline Total & 63 & 100.0 \\
\hline Age & 140 & 16.4 \\
\hline Less than 25 years & 119 & 36.4 \\
\hline 25-35 years & 63 & 30.9 \\
\hline $36-45$ years & 385 & 16.4 \\
\hline More than 45 years & 100.0 \\
\hline Total & \multicolumn{2}{|l|}{} \\
\hline
\end{tabular}

The above table above indicates that $54.5 \%$ of the subjects hold a high school degree or less. It also shows that $10.9 \%$ of the subjects hold a diploma degree and $30.9 \%$ of them hold a bachelor degree. While the rest of the subjects hold higher degrees. This table also shows that the number of females exceeds the numbers of males. As for the sample's marital status, the table shows that $20 \%$ of the respondents are single, while $72.7 \%$ of the respondents are married. As for the age, the majority of the respondents $(83.6 \%)$ do not exceed 45 years old.

In addition, $69.1 \%$ of the respondents have a past experience of dealing with NGOs'. Furthermore, the calculated average of the respondent's income is $344 \mathrm{JD}$.

Means and standard deviations of the study's variables and statements were summarized as follows:

Table2. Means and Standard Deviations of the Respondents' Attitudes towards the Study's Variables

\begin{tabular}{|l|l|l|}
\hline Statement & Arithmetic Mean & Standard Deviation \\
\hline Service & 3.5535 & .49049 \\
\hline Price & 3.1212 & .71829 \\
\hline Place & 3.4091 & .74620 \\
\hline Promotion & 3.3909 & .81459 \\
\hline Total & 3.4255 & .45964 \\
\hline
\end{tabular}

Table 2 indicates that the respondents have positive attitudes towards the aforementioned variables, because their means exceed the mean of scale (3). The grand mean also reflects that the respondents have positive attitudes towards all the study's variables.

The following pyramid shows the significance of each variable from the respondents' perspective: 


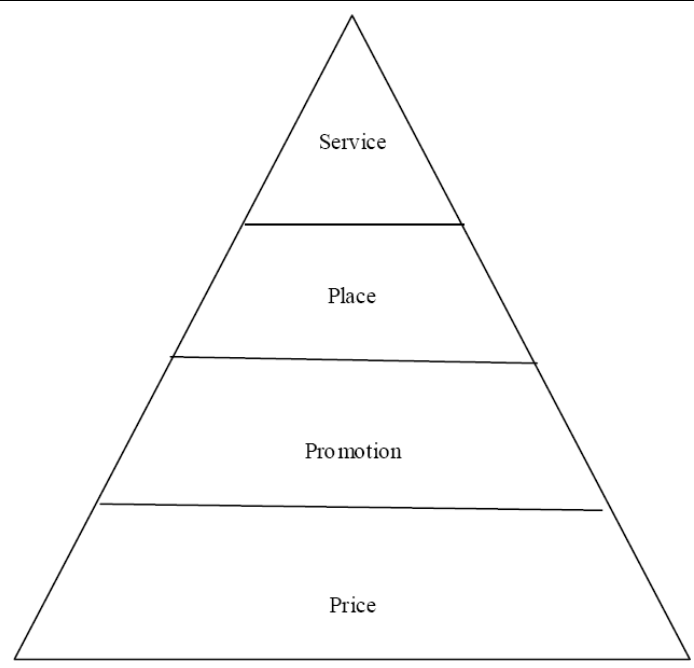

Source: Statistical analysis

\subsection{Results Related to the $1^{\text {st }}$ Question}

H01 - Customers have negative attitudes towards applying the marketing mix in NGOs.

Table3. Testing Hypothesis (1)

\begin{tabular}{|l|l|l|l|}
\hline & $\mathbf{N}$ & Arithmetic Mean & Std. Deviation \\
\hline Service & 385 & 3.5535 & .49049 \\
\hline Price & 385 & 3.1212 & .71829 \\
\hline Place & 385 & 3.4091 & .74620 \\
\hline Promotion & 385 & 3.3909 & .81459 \\
\hline TOTAL & 385 & 3.4255 & .45964 \\
\hline
\end{tabular}

\begin{tabular}{|l|l|l|l|l|l|l|}
\hline \multicolumn{2}{|l|}{ One-Sample T Test } \\
\hline & $\mathbf{t}$ & $\mathbf{d f}$ & $\begin{array}{l}\text { Sig. } \\
\text { (2-tailed) }\end{array}$ & $\begin{array}{l}\text { Mean } \\
\text { Difference }\end{array}$ & \multicolumn{2}{l|}{$\mathbf{9 5 \%}$ Confidence Interval of the Difference } \\
\cline { 6 - 8 } & & & Lower & Upper \\
\hline Service & 22.144 & 384 & $.000^{* *}$ & .55354 & .5044 & .6027 \\
\hline Price & 3.311 & 384 & $.001^{* *}$ & .12121 & .0492 & .1932 \\
\hline Place & 10.757 & 384 & $.000^{* *}$ & .40909 & .3343 & .4839 \\
\hline Promotion & 9.416 & 384 & $.000^{* *}$ & .39091 & .3093 & .4725 \\
\hline Total & 18.162 & 384 & $.000^{* *}$ & .42545 & .3794 & .4715 \\
\hline
\end{tabular}

** At the significance level of 0.01

One sample t test was conducted to test the above hypothesis. The calculated (t) values for each variable are significant at the significance level of (0.01). Thus, this means that the aforementioned null hypothesis is not accepted. Thus, that means that the study's respondents have positive attitudes towards applying the marketing mix in NGOs.

\subsection{Results Related to the $2^{\text {nd }}$ Question}

H02 - There are no differences that are statistically significant in the sample's attitudes towards applying the marketing mix in NGOs, which can be attributed to their past experience of dealing with NGOs.

Table4. Testing Hypothesis (2)

\begin{tabular}{|l|l|l|l|l|l|}
\hline \multirow{2}{*}{ Service } & & $\mathbf{N}$ & Mean & Std. Deviation & The “t” value \\
& yes & 266 & 3.4708 & .47944 & $-5.110^{* *}$ \\
\cline { 2 - 6 } & No & 119 & 3.7386 & .46551 & \\
\hline \multirow{3}{*}{ Price } & yes & 266 & 3.0439 & .69451 & $-3.197 * *$ \\
\cline { 2 - 6 } & No & 119 & 3.2941 & .74305 & \\
\hline \multirow{3}{*}{ Promotion } & yes & 266 & 3.4474 & .75176 & 1.507 \\
\cline { 2 - 6 } & No & 119 & 3.3235 & .72949 & -1.539 \\
\hline \multirow{2}{*}{ Total } & yes & 266 & 3.3465 & .78450 & \\
\cline { 2 - 6 } & No & 119 & 3.4902 & .87341 & $-3.788^{* *}$ \\
\cline { 2 - 6 } & yes & 266 & 3.3671 & .42805 & \\
\hline
\end{tabular}

** At the significance level of 0.01 

(NGOs)

Independent sample $t$ test was conducted to test the above hypothesis. The calculated (t) values for each of the following variables (service, price and marketing mix) are significant at the significance level of (0.01). Thus, this means that there are differences that are statistically significant in the respondents' attitudes towards applying (service, price and marketing mix) in NGOs, that can be attributed to their past experience of dealing with NGOs. Furthermore, these differences tend to increase in the ones who have no past experience of dealing with NGOs.

\subsection{Results Related to the $3^{\text {rd }}$ Question}

H03 - There is no relationship that is statistically significant between the sample's attitudes towards applying the marketing mix in NGOs and their income.

Table5. Testing Hypothesis (3)

\begin{tabular}{|l|l|l|}
\hline \multicolumn{2}{|l|}{} & income \\
\hline \multirow{4}{*}{ Service } & Pearson Correlation & .004 \\
\cline { 2 - 3 } & Sig. (2-tailed) & .942 \\
\cline { 2 - 3 } & $\mathrm{N}$ & 287 \\
\hline \multirow{5}{*}{ Price } & Pearson Correlation & -.039 \\
\cline { 2 - 3 } & Sig. (2-tailed) & .515 \\
\cline { 2 - 3 } & $\mathrm{N}$ & 287 \\
\hline \multirow{5}{*}{ Promotion } & Pearson Correlation & -.010 \\
\cline { 2 - 3 } & Sig. (2-tailed) & .872 \\
\cline { 2 - 3 } & $\mathrm{N}$ & 287 \\
\hline \multirow{5}{*}{ Total } & Pearson Correlation & .012 \\
\cline { 2 - 3 } & Sig. (2-tailed) & .842 \\
\cline { 2 - 3 } & $\mathrm{N}$ & 287 \\
\hline & Pearson Correlation & -.002 \\
\cline { 2 - 3 } & Sig. (2-tailed) & .968 \\
\cline { 2 - 3 } & $\mathrm{N}$ & 287 \\
\hline
\end{tabular}

Pearson correlation was conducted to test the above hypothesis. The calculated (r) values for each variable are not considered significant at the significance level of (0.05). Thus, this means that the aforementioned null hypothesis is accepted, which means that there is no relationship that is statistically significant between the respondents' attitudes towards applying the marketing mix in NGOs and their income.

\section{CONCLUSIONS AND RECOMMENDATIONS}

\subsection{Conclusions}

This study aimed to investigate the attitudes of the beneficiaries - who benefit from services or goods - towards applying the marketing mix in NGOs, which are commonly known through the abbreviation 4P's. The findings of this research indicate that the 4Ps are seen as being significant to manage marketing (Nuseir and Madanat, 2015) (Singh, 2012). The results of this study suggest that the service element (3.5535) was the most significant element. This finding is considered consistent with the results of (Nuseir and Madanat, 2015) (Lamb et al., 2011) (Cirikovic, 2014). What follows it in significance is the element of place (3.4091), then promotion (3.3909) and finally price (3.1212). Price was considered the least significant element by the perspectives of beneficiaries when applying the marketing mix in NGOs. These results differ from the results of (Kamau et al., 2015) who believe that price is the most significant element in the marketing mix, followed by service, location and then promotion. Thus, (Kamau et al., 2015) considered promotion the least significant element. As for (Al Muala and Al Qurneh, 2012), they believe that the element of place was the most important element.

\subsection{Recommendations}

With referring to the results of the statistical analysis and the hypotheses testing, the researchers recommend communities and NGOs to do the following:-

a. Give more attention to products and services that they offer,

b. Make the price compatible with the service being offered.

c. Conduct more research and studies that are concerned with NGOs and methods of developing them 
d. Provide training courses for the employees that are concerned with marketing, so that such courses shall seek to strengthen their skills and experience. Such courses shall also help them in adopting modern marketing programs that can help them in improving the level of marketing in organization.

The researchers also recommend government agencies to do the following:

a. Provide a conducive environment

b. Provide a competent attention to marketing legislation.

c. Finance training programs, and media support for these organizations.

\section{REFERENCES}

Al-Muala, Ayed \& Al-Qurneh, Majed (2012). Assessing the relationship between marketing mix and loyalty through tourists' satisfaction in Jordan curative tourism. American Academic \& Scholarly Research Journal, 4(2).

Armstrong, G. and Kotler, P. H (2011). Marketing introduction, $10^{\text {th }}$ edition, New Jersey: Person Education.

Baines, Paul \& Fill, Chris (2014). Marketing, $3^{\text {rd }}$ edition, Oxford University Press, London.

Bee, Ang Hooi (2009). Market share strategies in the pharmaceutical industry, Unitar E-Journal, 5(1), pp: 50-67.

Brace-Govan, J., Brady, E., Brennan, L., \& Conduit, J. (2011). Market orientation and marketing in non-profit organizations - indications for fundraising. Victoria International Journal of Nonprofit and Voluntary Sector Marketing, 16(1), pp: 84-98.

Cirikovic, Elida(2014). Marketing mix in tourism. Academic Journal of Interdisciplinary Studies, 3(2), pp: 111-115.

Cramer, Aron (2001). Business for Social Responsibility, Ray Design, San Francisco.

Galaskiewicz, J. \& Bielefeld, W. (1998). Nonprofit Organizations in an Age of Uncertainty: A Study of Organizational Change. New York: Aldine De Gruyter.

Kamau, Flourence, Wameru. F, Lewa, Peter and Misiko. A (2015). The Effects of the marketing mix on choice of tourist accommodation by domestic tourists in Kenya. International Journal of Novel Research in Marketing Management and Economics, 2(2), pp: 25-34.

Keegan, J. W., \& Green, M. C. (2011). Global Marketing, (6th ed.). New Jersey: Pearson Education.

Kotler, Philip(2011). Reinventing Marketing to Manage the Environmental Imperative. Journal of Marketing, vol(75), pp: 132-135.

Lamb, Charles. W., Hair, Joseph and McDaniel, Carl (2011). Marketing, (11 ${ }^{\text {th }}$ ed), South-Western, US.

Li, M. L., \& Green, R. D. (2010). A mediating influence on customer loyalty: The role of perceived value, Journal of Management and Marketing Research.

Macedo, I. and Pinho, J.C. (2003). "Re-defining the construct of market orientation in the non-profit sector: an exploratory study", in Saren, M. and Wilson, A. (Eds), Marketing Responsible and Relevant? Track 7.6.4. International Marketing Proceedings of the 32nd EMAC Conference, Glasgow.

Macedo, Isabel and Pinho, Jose (2006). The relationship between resource dependence and market orientation. European Journal of Marketing, 40(5/6), pp: 533-553.

Malhotra, N. K. (2004). Marketing research. New Jersey: Prentice Hall

Markgraf, B. (2015). Eight P's in marketing tourism. Texas: Hearst Newspapers, LLC. Retrieved from http://smallbusiness.chron.com/eight-ps-marketing-tourism-42140.html. Accessed on 20.04.2015

Middleton, V. and Clarke, J. (2001). Marketing in Travel and Tourism, $3^{\text {rd }}$ edition, Oxford: Butterworth-Heinnman.

Nuseir, Mohammed \& Madanat, Hilda (2015). 4Ps: A strategy to secure customers' loyalty via customer satisfaction. International Journal of Marketing Studies, 7(4), pp (78-87).

Peter, J. Paul \& Donnely, James (2016). A Preface to Marketing Management, $14^{\text {th }}$ edition, McGrawHill Global Education Holdings, LLC. 
Pomering, Alan, Johnson,Lester, and Noble, Gary (2010). Conceptualizing a contemporary marketing mix for sustainable tourism marketing. Proceedings of the $20^{\text {th }}$ Annual Conference of the Council for Australian University Tourism and Hospitality Education, pp:1-15

Sara, Dolnicar, and Katie, Lazarevski (2009). Marketing in non-profit organizations. International Marketing Review, 26(3), pp: 275-291.

Singh, Meera (2012). Marketing mix of 4P's for competitive advantage. Journal of Business and Management, 3(6), pp: (40-45).

Wymer, W \& Gomes, R \& Knowles, PA. (2006), Non-profit marketing: marketing management for charitable and non-governmental organizations, Sage Publications

Yazdanifard, Rashed, Massoumian, Melika. \& Karimi, Mohammad (2013). Structure of nongovernmental organization marketing. International Journal of Management, Accounting and Economics. 